\title{
The Effect of Hedonic Shopping Motivation, Shopping Lifestyle And Fashion Involvement With Impulse Buying
}

\author{
Satria Tirtayasa $^{1}$, Myisha Nevianda ${ }^{1}$, Hery Syahrial ${ }^{2}$
}

\begin{abstract}
The purpose of this research is to analyse the direct Effect of Hedonic Shopping Motivation, Shopping Lifestyle and Fashion Involvement with Impulse Buying. The population of this research is Zalora's customer in Medann are unknown, The sample size 96 respondents with using Bernoulli formula sample sise measurement. Meanwhile, the respondents have criteria, such as: respondent expenditure more than $R p 1.500 .000,-$, ever bought on Zalora more than three time, and the counsumer are the active internet user in Medan(purposive sampling). Data collection was used the Google form questionnaire and the data analysis method is used associative statistical analysis and Partial-Least Square analysis (SEMPLS). The results of the research showed that the Hedonic Shopping Motivation variable had significant effect with Impulse Buying, the Shopping Lifestyle variable has significant effect with Impulse Buying and the Involvement Fashion variable has significant effect with Impulse Buying.
\end{abstract}

Keywords: Hedonic Shopping Motivation, Shopping Lifestyle,

Fashion Involvement, Impulse Buying. Cameroon

DOI : https://doi.org/10.30596/ijbe.v2i1.5715

JEL Classification: M00, M3, M31

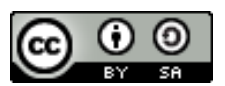

Published by International Journal of Business Economics (IJBE), Indonesia | Copyright (C) 2020 by the Author(s) | This is an open access article distributed under the Creative Commons Attribution License http://creativecommons.org/licenses/by/4.0), which permitsunrestricted use, distribution, and reproduction in any medium, provided the original work is properly cited.

Cite this article as:

Tirtayasa, S., Nevianda, M., \& Syahrial, H. (2020). The Effect of Hedonic Shopping Motivation, Shopping Lifestyle And Fashion Involvement With Impulse Buying. International Journal of Business Economics (IJBE), 2(1), 1828.

${ }^{I}$ Fakultas Ekonomi Dan Bisnis, Universitas Muhammadiyah Sumatera Utara

Jl. Kapten Mukhtar Basri No. 3 Medan, Indonesia

${ }^{2}$ Universitas Medan Area, Medan, Indonesia

*Corresponding Author: satriatirtayasa@umsu.ac.id 


\section{International Journal of Business Economics (IJBE)}

Vol, 2 Issue 1, pp 18-28, Sept 2020

http://jurnal.umsu.ac.id/index.php/ijbe

eISSN 2686-472X

\section{INTRODUCTION}

E-commerce have been a trend of business especially for big town in Indonesia, for instance Medan city. Based on surveyed of CNN (2018) some of the young person who live in big city using online shopping compare with traditional shopping..

One of the e-commercebusiness that have exist of online business is Zolora. Zolora gives many of accessibility transaction, reliable delivery and new product offer of consumer that can influence consumer more hedonic buying. Most of consumer transaction product are fashion product, such as : clothes, cosmetic, accessories, shoes, etc. Most of Medan citizen woman, especially Middle class chose Zolora products because it has a good quality and branded product and low price.

Through Internet media, this condition can definitely facilitate consumers to find their needs by not forgetting always compare the price of each supplier who offers the products of Suprihartini in (Arda \& Adriany, 2019). It has the potential to happen to buy or purchase impulsivity online. Consumer behaviour in Indonesia, one of which is not having any planning in shopping (Impulsive buying).

Interest in lifestyle shopping in the community especially the most prominent women are fashion products. Fashion can affirm a person's identity to the social environment. According to Moth (2012), "improved online consumer behaviour can also increase the likelihood for an unplanned purchase online".

The consumers will not care and think first to have the products it wants, this will make them very easy to order products through Zalora. At first just look-clay but will eventually be attracted to a product so there is an unplanned purchase (impulse buying). The purchase of an impulse buying consumer can be based on lifestyle changes in shopping lifestyle and (fashion involvement).

The influence of impulsive purchases in this study was an internal factor that included the tendency to purchase impulsivity, psychological conditions and normative evaluation. Often consumers experience impulse buying when encouraged by the desire of hedonistic (hedonic shopping motivation) or other causes beyond economic reasons, such as a sense of delight, social or emotional influence. Because they consider that when shopping is a pleasure in its own when what they need before is not met, then once fulfilled do not see the benefits on the product, which makes the emergence of a new need in the sense of a person has a separate satisfaction on a product they have ever bought so when they see other items with the same product they become interested to buy it even from the beginning has no planning. When people find products that are difficult to locate in a store, they will buy the product even if they do not plan it.

Consumers are now smarter in choosing trusted, secure online shopping and giving them the feeling of being satisfied when doing shopping transactions. The hedonist desires experienced by a consumer when making a purchase, and make the lifestyle of one's shopping complex so it's no wonder then the number of a consumer is tempted to shop for a lifestyle need. The increasing number of offers and the number of local and overseas products in Zalora online shop, is expected to encourage consumers to do shopping transactions. According to (Pradiningtyas, 2019), the use or selection of online-based shopping by consumers can be determined by the buying behavior of consumers. Many things can change the habits of people in doing shopping transactions such as shopping lifestyle, fashion involvement, hedonic shopping motivation, or impulse buying and others.

Zalora is the largest fashion ecommerce site in southeast Asia. Zalora Indonesia was established in 2012 and is the fastest growing online fashion retail in Asia. Zalora 


\section{International Journal of Business Economics (IJBE)}

Vol, 2 Issue 1, pp 18-28, Sept 2020

http:/ /jurnal.umsu.ac.id/index.php/ijbe

eISSN 2686-472X

Indonesia created a website zalora.co.id for consumers to access and see the products offered as well as all the complete information about Zalora Indonesia. By shopping in Zalora at this time will be an activity of hedonic shopping motivation loved by customers because they think the shopping will cause a feeling of delight, happy, and can fill their time with shopping and with a variety of offers offered by Zalora. Shopping Lifestyle or lifestyle is influential with a person's interest in a product that can lead to the behavior of hedonistic that will be influential or resulted in an unplanned purchase and Zalora is one of the E-Commerce start-up.

Based on the background of the problem, researchers chose the influence of hedonic shopping motivation, shopping lifestyle and fashion involvement to Zalora customers in the city of Medan.

An impulsive purchase is a pre-planned purchase action or purchase decision made while in the store. The purchase of an impulse buying consumer can be based on a change in lifestyle shopping which is increasingly varied. (Engel, Blavkwell, \& Miniard, 1995).

According to Rook in (Nurcholish, 2017), impulse buying is a shopping behaviour that occurs unplanned, emotionally interested, where the decision making process is done quickly without thinking wisely and consideration of the overall information and alternatives.

According to Loudon and Bitta (Anin, Rasimin, \& Atamimi, 2012), there are factors that affect Impulse Buying as follows: 1) products with the characteristics of cheap price, small or marginal needs, short-term products, and small size. 2) Marketing and marketing that includes distribution in a number of outlets that are self service, advertising through mass media is very suggestive and continuous, advertising at the point of sale. 3) Consumer characteristics such as personality, gender, social demographics or social economic characteristics.

According to Arnold \& Reynolds, (2003), the motivation of hedonistic is a lifedriven buying activity that relates to the five senses, disappointment and emotion makes the material pleasure and pleasure a primary goal. Hedonic shopping motives is a psychological necessity such as contentment, prestige, emotion, and other subjective feelings. This need often appears to meet social and aesthetic demands and is also called an emotional motif (Setiadi, 2003).

According to Utami (2010), the presence of indicators that affect hedonic shopping motivation as follows: 1) shopping is a very interesting experience. 2) shopping is an alternative to overcoming boredom. 3) Consumers prefer to shop in addition to themselves. 4) Consumers prefer to find shopping places that offer discounts and cheap prices. 5) The trust in shopping will be created as they spend time with family or friends. 6) Consumers shop to follow the trend of new models.

According to Levy, (2009), shopping lifestyle is a lifestyle that refers to how a person lives, how they spend their time, money, buying activities, attitudes and opinions about the world in which they live. The person's lifestyle in spending the money makes a new trait and characteristic of an individual. Jackson in (Japarianto \& Sugiharto, 2011), said shopping lifestyle is an expression of lifestyle in shopping reflecting the difference of social status.

According to Cobb in (Japarianto \& Sugiharto, 2011), a lifestyle shopping indicator, as follows: 1) responding to purchasing any advertising offers regarding fashion products. 2) Buy the latest model clothes when viewing it. 3) Shop for the most famous brands. 4) confident that the famous brand (product category) is in the best buy in terms of quality. 5) 


\section{International Journal of Business Economics (IJBE)}

Vol, 2 Issue 1, pp 18-28, Sept 2020

http:/ /jurnal.umsu.ac.id/index.php/ijbe

eISSN 2686-472X

often buy various brands (product categories) from the usual brands in the buy. 6) Sure there are other brands (product categories) that are the same as those purchased.

According to Paul Peter and Jerry C. Olson (2013) involvement is an motivational condition that energizes and directs the consumer's cognitive and effective processes and behavior at the time of decision making. Fashion involvement refers to the extent to which one is exploring a number of fashion-related concepts, including awareness, knowledge, interests, and reactions. Involvement is a state of motivation of interest or interest generated by the stimulus or situation, and is displayed through the nature of such encouragement o'cass in (Park, 2005).

According to Japarianto \& Sugiharto, (2011), the existence of a fashion indicator involvement as follows: 1) has one or more garments with the latest model (trend). 2) Fashion is an important thing that supports activities. 3) prefer when the model of clothing used differs from the other. 4) clothing shows characteristics. 5) can know a lot about someone with the clothes used. 6) When wearing favorite clothes, make others interested in seeing them. 7) Try a fashion product first before buying it. 8) Knowing the latest fashion compared to others.

Rahma \& Septrizola, (2019) and Handayani \& Arda, (2019), concluded that there was a significant relationship between hedonic shopping motivation on impulse buying.

H1: Hedonic Shopping Motivation has significant impact on Impulse Buying

Usvita, (2016), Chusniasari, (2015) and Kosyu, Hidayat, \& Y, (2014), concluded that there was a significant relationship between the lifestyle shopping of impulse buying.

H2: Shopping Lifestyle has significant impact on Impulse Buying

Japarianto \& Sugiharto, (2011), Chusniasari, (2015) and Kosyu, Hidayat, \& Y, (2014); Prasita, (2013), concluded that involvement fashion has significant effect on impulse buying.

H3: Fashion Involvement has significant effect on impulse buying

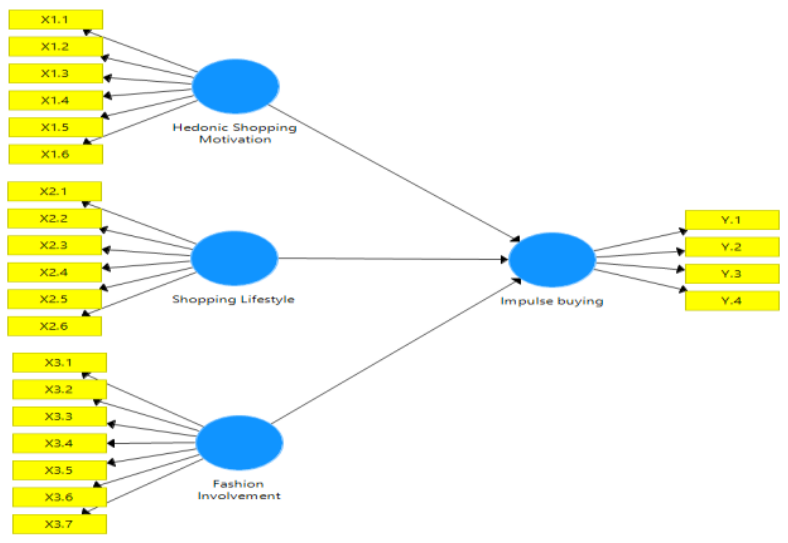

Figure 1. Conceptual framework

\section{METHODS}

The type of research used in this study is an associative approach used because it uses two or more variables and its purpose to figure out the influence between variables. Types of research used with quantitative approaches. The goal is to test hypotheses or answer questions related to the subjects being researched. The population in this research is Zalora customers in the city of Medan, because the population is unknown hence the determination of the number of samples using Bernoulli formula amounting to 96 people. 


\section{International Journal of Business Economics (IJBE)}

Vol, 2 Issue 1, pp 18-28, Sept 2020

http://jurnal.umsu.ac.id/index.php/ijbe

eISSN 2686-472X

This research uses Purposive Sampling, where the population selected based on the criteria: 1) Respondents have the expenditure $\geq \mathrm{Rp} 1.5$ million, 2) respondents have been shopping in Zalora more than 3 times, 3) Consumers of active Internet users in Medan. Data analysis using multiple linear regression.

\section{RESULTS AND DISCUSSION Construct Reliability and Validity}

The statistics used in the composite reliability or the Konstrak reusability is the composite reliability $>6.0$ indicates that the conjunction has a high reusability or reliability as a measuring instrument. Limit value $>0.6$ means acceptable and above 0.8 and 0.9 means very satisfactory. (Bagozzi \& Yi, 1988).

Table 1. Result Composite reliability

\begin{tabular}{cc}
\hline & Composite Reliability \\
\hline Hedonic shopping motivation & 0.878 \\
Shopping lifestyle & 0.940 \\
Fashion Involvement & 0.888 \\
Impulse buying & 0.955 \\
\hline
\end{tabular}

The conclusion of the testing of composite reliability is as follows:

1. The hedonic shopping motivation variable is reliable, because the value of composite reliability hedonic Shopping motivation is $0878>0.6$.

2. Lifestyle shopping variables are reliable, because the value of composite reliability shopping lifestyle is $0940>0.6$.

3. The involvement fashion variable is reliable, because the value of involvement composite reliability is $0888>0.6$.

4. The impulse buying variable is reliable, as the composite reliability impulse buying value is $0955>0.6$.

\section{Average Variance Extracted (AVE)}

Average Variance Extracted (AVE) describes the size of Variance that can be described by items compared to variants caused by error measurement. By default is the value of the AVE $>0.5$ Then it can be said that the construct has a good validity convergent. This means that latent variables can explain on average more than half the variance of the indicators.

Table 2. Average Variance Extracted (AVE)

\begin{tabular}{lc}
\hline & Average Variance Extracted \\
\hline Hedonic shopping motivation & 0.546 \\
Shopping lifestyle & 0.724 \\
Fashion Involvement & 0.537 \\
Impulse buying & 0.842 \\
\hline
\end{tabular}

The conclusion of testing Average Variance Extracted is as follows: ariable hedonic shopping motivation, The lifestyle-shopping, Involvement fashion, and The impulse buying are reliables, because the value of the Average Variance Extractedhedonic shopping motivation are $>0.5$. 


\section{International Journal of Business Economics (IJBE)}

Vol, 2 Issue 1, pp 18-28, Sept 2020

http://jurnal.umsu.ac.id/index.php/ijbe

eISSN 2686-472X

\section{Discriminant Validity}

The sense of linear validity (the validity of discrimination) is the extent to which a construction is completely different from other constructions (the construct is unique) (Juliandi, 2018) The best new measurement criteria is to look at the value of HeretroitMonotrait Ratio (HTMT). If the HTMT value is $<0.90$ then a construction has good discriminant validity according to Jörg Henseler Christian; M. Ringle; Marko Sarsted (Juliandi, 2018).

Table 3. Discriminant Validity

\begin{tabular}{ccccc}
\hline & \multicolumn{4}{c}{ Discriminant Validity } \\
\cline { 2 - 5 } & $\begin{array}{c}\text { Hedonic } \\
\text { Shopping } \\
\text { Motivation }\end{array}$ & $\begin{array}{c}\text { Shopping } \\
\text { Lifestyle }\end{array}$ & $\begin{array}{c}\text { Fashion } \\
\text { Involvement }\end{array}$ & Impulse buying \\
\hline $\begin{array}{c}\text { Hedonic } \\
\text { Shopping }\end{array}$ & & & 0.836 & \\
Motivation & & & \\
Shopping & 0.513 & 0.865 & 0.754 \\
$\begin{array}{c}\text { Lifestyle } \\
\text { Fashion }\end{array}$ & & & & \\
Involvement & & & 0.890 & \\
Impulse buying & 0.719 & & \\
\hline
\end{tabular}

The conclusion of the testing of Heretroit-Monotrait Ratio (HTMT) is as follows:

1). Hedonic Shopping Motivation on shopping lifestyle has a Heretroit-Monotrait Ratio of $0513<0.90$, meaning either discriminant validity, or completely different from other constructions (the construct is unique).

2). The hedonic shopping motivation variable against impulse buying is a HeretroitMonotrait Ratio of $0719<0.90$, meaning a good discriminant validity, or different from other constructions (the construct is unique).

3). The involvement fashion variable against the impulse buyingvalue of HeretroitMonotrait Ratio $0890<0.90$, meaning the validity of either discriminant, or distinct from other constructions (the construct is unique).

4). Involvement fashion variables against the shopping lifestyle Heretroit Monotrait Ratio of $0865<0.90$, meaning the validity of good discrimination, or different from other constructions (the construct is unique).

5). The involvement fashion variable against hedonic shopping motivation the value of Heretroit Monotrait Ratio $0836<0.90$, meaning either discriminant validity, or completely different from other constructions (the construct is unique).

6). The impulse-buying variable on the shopping lifestyle of Heretroit Monotrait Ratio $0754<0.90$, meaning the validity of good discrimination, or different from other constructions (the construct is unique)

\section{Multiple linear regression}

Multiple linear regression intends to analyse the direct influence of good hedonic shopping motivation against impulse buying; Lifestyle shopping against impulse buying; and fashion involvement against impulse buying., to assess the significance of multiple linear regression can be seen from the test (critical ratio) obtained from the bootstrapping 


\section{International Journal of Business Economics (IJBE)}

Vol, 2 Issue 1, pp 18-28, Sept 2020

http://jurnal.umsu.ac.id/index.php/ijbe

eISSN 2686-472X

process (Resampling method).R-Square. The definition of R-Square is a proportion of the variation in the value of an affected variable (endogenous) that can be explained by a variable influencing it (exogenous). It's useful to predict whether the model is good/bad. (Juliandi, 2018).

The criteria of R-Square (Juliandi, 2018) are: 1). If the value of R2 (adjusted) $=0.75$ $\rightarrow$ Model is substantial (strong), 2) If the value R2 (adjusted) $=0.50 \rightarrow$ Model is $\mathrm{m}$, oderate (moderate), 3 ). If the value of $\mathrm{R} 2$ (adjusted) $=0.25 \rightarrow$ The Model is weak (bad).

The Conclusion of The Test R-Square Value On Is As Follows: R-Square Adjusted linear regression $=0679$. This means that the capability of the variable $\mathrm{X} 1, \mathrm{X} 2, \mathrm{X} 3$ in explaining Y (impulse buying) is $67.9 \%$ thus the model is moderate (moderate).

The definition of F2 effect size (F-Square) is a measure used to assess the relative impact of a variable that affects (exogenous) against an affected variable (endogenous). Changes of Strongswan R2 when certain exogenous variables are eliminated from the model, can be used to evaluate whether the omitted variables have a substantive impact on the endogenous construction. The criteria of F-Square according to are as follows:

1. The Hedonic Shopping Motivation variable against Impulse buying has a value of F2 = 0048, so a small effect of an exogenous variable against endogenous

2. Variable Shopping Lifestyle against Impulse buying has a value of F2 $=0110$, hence a small effect of an exogenous variable towards endogenous.

3. The involvement fashion variable against impulse buying has a value of $F 2=0166$, hence the moderate effect of an exogenous variable against endogenous

\section{Direct Effect}

The purpose of the direct effect analysis is useful to test the immediate effect hypothesis of a variable that affects (exogenous) the affected variable (endogenous) (Juliandi, 2018)

Table 4. Direct Effect

\begin{tabular}{ccccccc}
\hline & $\begin{array}{c}\text { Original } \\
\text { Sample } \\
(\mathbf{O})\end{array}$ & $\begin{array}{c}\text { Sample } \\
\text { Mean } \\
(\mathbf{M})\end{array}$ & $\begin{array}{c}\text { Standard } \\
\text { Deviation } \\
(\text { STDEV) }\end{array}$ & $\begin{array}{c}\text { T Statistics } \\
(\mid \mathbf{O} / \text { STERR|) }\end{array}$ & $\begin{array}{c}\text { P- } \\
\text { Value }\end{array}$ & t table \\
\hline $\begin{array}{c}\text { Hedonic shopping } \\
\text { motivation->impulse } \\
\text { buying }\end{array}$ & 0.181 & 0.186 & 0.072 & 2.528 & 0.012 & 1,982 \\
$\begin{array}{c}\text { Shopping lifestyle } \\
\text { >impulse buying }\end{array}$ & 0.288 & 0.293 & 0.084 & 3.421 & 0.001 & 1,982 \\
$\begin{array}{c}\text { Fashion involvement } \\
\text {->impulse buying }\end{array}$ & 0.454 & 0.450 & 0.117 & & & \\
\end{tabular}

The conclusion of the direct effect value in the 4.11 table is as follows:

1. The effect of Hedonic shopping motivationwith impulse buying can be showed by linear regression $=2,528>\mathrm{T}$-table $=1.982$ that is, the influence Hedonic shopping motivation against impulse buying is positive and significant. 


\section{International Journal of Business Economics (IJBE)}

Vol, 2 Issue 1, pp 18-28, Sept 2020

http:/ /jurnal.umsu.ac.id/index.php/ijbe

eISSN 2686-472X

2. The effect of Shopping Lifestyle with Impulse buying can be showed by Linear regression $=3,421>\mathrm{T}$-table $=1.982$ that is, the effect of Shopping for impulse buying is positive and significant.

3. The effect of Fashion Involvementa with Impulse buying can be showed by Linear regression $=3,889>$ T-table $=1.982$, that is, the influence of Fashion Involvementagainst impulse buying is positive and significant.

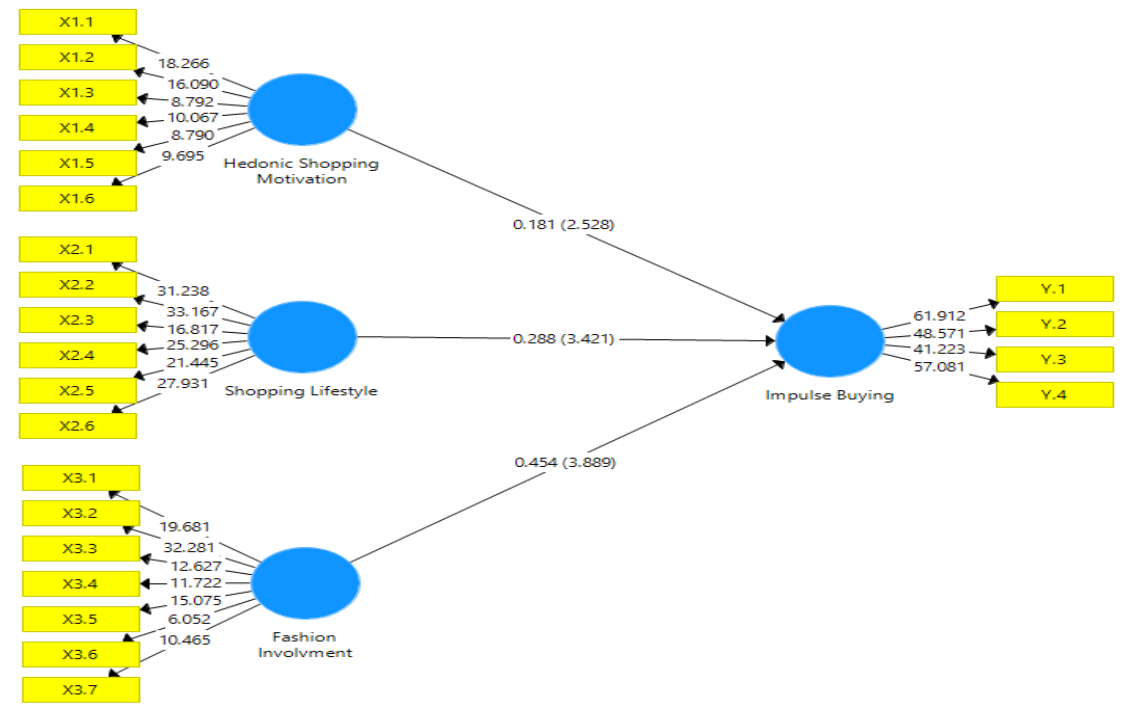

Figure. 2. T-Value Inner and Outer Model.

\section{Discussion}

Hedonic Shopping Motivation influence on Impulse buying According to (Kim, 2006) Hedonic shopping motivation played an important role in the purchase of impulsivity. Therefore, often consumers experience an impulsive purchase when encouraged by the desire of hedonistic or other reasons beyond economic reason, such as the likes of a product, happy, socially or because of emotional influence. This is supported by previous research conducted by Anita (2018), (Rahma \& Septrizola, 2019) and (Handayani \& Arda, 2019), concluded that hedonic shopping motivation significant effect on impulse buying. Likewise, the result of this research is done in Zalora customers in the city of Medan that the compound considers hedonic shopping motivation should make planning.The effect of Shopping Lifestyle on Impulse Buying According to (Levy, 2009), lifestyle is referring to how a person lives, how they spend their time and money, the buying activities made, their attitudes and their opinions about the world in which they live. This is in line with previous research conducted by Yulisyanti (2016), (Chusniasari, 2015) and (Kosyu, Hidayat, \& Y, 2014), concluded that the shopping lifestyle significantly affects impulse buying. Similarly, the results of this research done to Zalora customers in the city of Medan that the dominant respondents agreed because they think, shopping is a fun thing, they are more interested in clothes that interest him and cause unplanned purchases. The effect of Fashion Involvement on Impulse Buying. According to Tirmisi, Fashion involvement is a level of interest that is embodied from the level of involvement of various things related to fashionable clothing or equipment. This is in line with previous research conducted by (Japarianto \& Sugiharto, 2011), (Chusniasari, 2015) and (Kosyu, Hidayat, \& Y, 2014), Prasita, 2013), concluded that involvement fashion has significant 


\section{International Journal of Business Economics (IJBE)}

Vol, 2 Issue 1, pp 18-28, Sept 2020

http://jurnal.umsu.ac.id/index.php/ijbe

eISSN 2686-472X

effect on impulse buying. Similarly, the results of this research conducted on the customers Zalora in the city of Medan that the dominant respondents agreed because according to them, one of the main according to the consumer is for fashion consumers is important to support the appearance of the purchase of clothing is not planned.

\section{Implication}

The businessman should be considering about the consumer behavior, especially the characteristic of hedonic buyer behavior such as prestige, consumer emotion, and other subjective feelings. More sensitive the businessman for that behaviors, it makes more higher advantages for business. Shopping Lifestyle shopping lifestyle has relationship with consumer status and economic level. Generally, More higher the consumer economy level. It makes more buyer activity. Fashion Involvement also has significant with impulsive buyer, for instance more simple the buying behavior process it can give more efficient time for consumer in making buyer decision. Thus, ecommerce business has appear to take this opportunities, because the trend buying behavior has been changed.

\section{CONCLUSION}

Based on data analysis and discussion on the effect of hedonic shopping motivation, shopping lifestyle and fashion involvement with impulse buying in Zalora customers in the city of Medan with the method of analysis used is linear regression, then it can be concluded on the first hypothesis Hedonic shopping motivattion significant effect on impulse buying in Zalora customers in the city of Medan. In the second hypothesis the Shopping lifestyle significantly affects impulse buying in Zalora customers in the city of Medan. Then the third hypothesis of Fashion involvementascendant significant to impulse buying on Zalora customers in the city of Medan.

\section{REFERENCES}

Anin, F. A., Rasimin, B., \& Atamimi, N. (2012). The Relationship of Self Monitoring Dengan Impulsive Buying With Young Product Fashion. Psikology Journal, 35(2), 181-193.

Arda, M., \& Adriany, D. (2019). Effect of Lonliness and Discount Price on Impule Buying in Teenage Girls. The 1 International Conference on Innovation of Small Mediumsized Enterprise, 1(1), 25-34.

Arifin, P., \& Sunarti. (2014). The Effect of Hedonic Shopping With Impulsive Buying at Online Shoop With Positive Emotional as Intervening Variable Administrasi Bisnis Journal, 8(2).

Arnold, M. J., \& Reynolds, K. E. (2003). Hedonic shopping motivation. journal of retailing, 79, 77-95.

Bachdar, S. (2018, June 26). Priceza. Takes from Marketeers.com: https://marketeers.com/lima-kota-indonesia-dengan-jumlah-pembelanja-onlineterbesar/

Chusniasari. (2015). The Effect of Shopping Lifestyle, Fashion Involvment dan Hedonic Shopping With Costumer Impulse Buying. Jurnal Ilmu dan Riset Manajemen, 4(12), $1-21$.

Dawson, S., \& Kim, M. (2009). External And Internal Trigger Cues Of Impulse Buying Online. Direct Marketing An International, 3(1). 


\section{International Journal of Business Economics (IJBE)}

Vol, 2 Issue 1, pp 18-28, Sept 2020

http://jurnal.umsu.ac.id/index.php/ijbe

eISSN 2686-472X

Eka, R. (2018, 07 04). Indonesian E-Commerce Landscap from Consumer Prepective: https://dailysocial.id/post/e-ecommerce-di-indonesia-2018/

Engel, J. F., Blavkwell, R. D., \& Miniard, P. W. (1995). Consumer Behavior. Jakarta: Binarupa Aksara.

Gunadhi, E., \& Japarianto, E. (2015). The Impact of Store Atmosphere with Impulse Buying from Shoppng Lifestyle dan Emotional Response sebagai Variabel Intervening pada The Body Shop Indonesia. Jurnal Manajemen Pemasaran Petra, 1(1), 1-9.

Handayani, S., \& Arda, M. (2019). Effect of Discount and Hedonic Shopping Motives Against Buying Impulse. The 1 International Conference pn Innovation of Small Medium sixed Enterprise, 1(1), 93-101.

Japarianto, E., \& Sugiharto, S. (2011). The Effect of Shopping Lifestyle dan Fashion Involvment terhadap Impulse Buying Behavior Masyarakat High Income. Jurnal Manajemen Pemasaran, 6(1), 32-41.

Juliandi, A. (2018, Desember 16-17). Structural equation model based partial least square (SEM-PLS): Using SmartPLS. Training of SEM-PLS Program Pascasarjana Universitas Batam.

Kim, S. (2006). Using Hedonic and Utilitarian Shopping Motivation to Profile Inner City Conusmer. Journal of Shopping Center Research, 13(1).

Kosyu, D. A., Hidayat, K., \& Y, A. (2014). The Effect of Hedonic Shopping Motives With Shopping Lifestyle And Impulse Buying), Jurnal Administrai Bisnis, 14(2), 17.

Levy, M. (2009). Retailing Management. Jakarta: Erlangga.

Lusliyanti, D. Y. (2016). The Effect of Hedonic Shopping Motivation and Shopping Lifestyle With impulse buying fashion product. SKRIPSI, 1-59.

Nurcholish, G. (2017). The Effect of shopping lifestyle, fashion involvement, hedonic shopping value and shop staff with impulse consumer buying behavior : Fakultas Ekonomi, Universitas Muhammadiyah Purworejo.

Park, E. J. (2005). A Structural Model of Fashion-Oriented Impulse Buying Behavior. Journal of Fashion Marketing and Management, 10(4).

Pasaribu, L. O., \& Dewi, C. K. (2015). The Effect of hedonic shopping motivation With impulse buying at Zalora online shop. Bina Ekonomi, 19(2).

Pradiningtyas, D. (2019). The Effect of Hedonic Shopping Value, Shopping Lifestyle and Positive Emotion with Online Consumer Impulse Buying. Journal Speed, 11(2), 1-8.

Prasita, F. E. (2013). The Effect of Shopping Lifestyle, Fashion Involvement and Hedonic Shopping Value With Impulse Elizabet Consumer Buying Behavior. Jurnal Ilmiah Mahasiswa Manajemen, 2(4).

Rahma, W. S., \& Septrizola, W. (2019). The Effect of Hedonic Shopping Motivation and Shopping Lifestyle With E-Impulse Buying of Padang Student. Jurnal Kajian Manajemen dan Wirausaha, 1(1), 276-282.

Rahmawati, A. (2018). The Effect of Hedonic Shopping Motivation and Sale Promotion With Positive Emotion and Impact with Impulse Buying atE-Commerce Berry Benka. Jakarta: Uin Syarif Hidayatullah Jakarta .

Scarpi, D. (2006). Fashion stores between fun and usefulness. Journal of Fashion Marketing and Management, 10(1). 


\section{International Journal of Business Economics (IJBE)}

Vol, 2 Issue 1, pp 18-28, Sept 2020

http://jurnal.umsu.ac.id/index.php/ijbe

eISSN 2686-472X

Sekarsari, L. (2013). The Effect service capes and Hedonic Shopping Value with Impulsif Buyer Decision of Female consumer at Giant Hypermart Mall Olympic Garden Malang. Jurnal Ilmiah Mahasiswa FEB, 2(1).

Semuel, H. (2005).Environment Response Buyer as Buyer Stimuli, Jurnal Manajemen dan Kewiraushaan, 7(2).

Setiadi, N. (2003). Consumer Behavior. Jakarta: Kencana.

Sugiyono. (2016). Research Methodology. Bandung: PT.Alfabet.

Tirtayasa, S., \& Puspowarsito, A. H. (2006). Impact of Order of Entry on Business Performance. Jurnal Manajaemen \& Bisnis Sriwijaya, 4(7).

Utami, C. W. (2006). Manajemen Ritel. Jakarta: Salemba Empat.

Utami, C. W. (2010). Manajemen Ritel. Jakarta: Salemba Empat.

Yistianti, N. N., Yasa, N. N., \& Suasana, I. G. (2012). The Effect of Atmosfer Gerai and Ritel Service With Hedonic Value and Implusif Buying at Matahari Department Store Duta Plaza di Denpasar. Jurnal Manajemen, 6(2), 139-148.

Zikmund, W. G., \& Babin, B. (2013). Marketing Research. Jakarta: Salemba Empat. 